\title{
Nacionalcatolicismo y celebraciones del «Año de la Victoria» a través de la Prensa del Movimiento: el caso de la provincia de Granada
}

\author{
National Catholicism and celebrations for the \\ "Year of the Victory» through the Official Falange \\ Press: the case in the Province of Granada
}

\author{
Miguel Ángel Carvajal Contreras \\ Universidad de Granada, España \\ macarvajalcont@gmail.com \\ https://orcid.org/0000-0002-2908-2404
}

Recibido: 02/05/2021

Aceptado: 16/10/2021

Cómo citar este artículo: CARVAJAL CONTRERAS, Miguel Ángel (2022). Nacionalcatolicismo y celebraciones del «Año de la Victoria» a través de la Prensa del Movimiento: el caso de la provincia de Granada. Pasado y Memoria. Revista de Historia Contemporánea, (24), pp. 239-266. https:// doi.org/10.14198/PASADO2022.24.10

\section{Resumen}

El presente trabajo aborda la relación entre el nacionalcatolicismo y la Prensa del Movimiento en la provincia de Granada, una vez finalizada la Guerra Civil, en 1939. Tras las muestras de iconoclastia y anticlericalismo previas a la guerra, que se habían desarrollado en algunas zonas del territorio provincial, el régimen franquista, junto con la Iglesia, llevaría a cabo un proceso de purificación simbólica del espacio público. Ello se hizo sobre la base de la exaltación del culto religioso, mediante eucaristías y rituales como procesiones y romerías, a lo que se añadió el culto a los caídos durante el conflicto. La prensa del régimen, vinculada especialmente al falangismo al inicio del mismo, mostraría prácticas religiosas unidas a celebraciones entorno al final de la guerra. 
Palabras clave: Nacionalcatolicismo; Religiosidad; Rituales; Franquismo; Granada.

\begin{abstract}
This paper deals with the relationship between National Catholicism and the Official Falange Press in the province of Granada once the Spanish Civil War was over, in 1939. After the signs of iconoclasm and anticlericalism previous to the war, which had developed in some parts of the provincial territory, Franco's regime, together with the Church, carried out a process of symbolic purification of the public space. This was done on the basis of exaltation of religious cult, through Eucharists and rituals such as processions and pilgrimages, as well as through worship of those fallen during the conflict. At the beginning of Franco's regime, the press particularly connected with Falange would display the religious practices linked to celebrations of the end of the war.
\end{abstract}

Keywords: National Catholicism; Religiosity; Rituals; Francoism; Granada.

\title{
Introducción
}

Uno de los elementos socioculturales que pudo aprovechar el régimen franquista para difundir su mensaje de victoria tras la Guerra Civil y que al vincularse a una determinada institución, como es la eclesiástica, pudo gozar de un apoyo más allá de los propios grupos sublevados (militares, falangistas, requetés, etc.), es el catolicismo, que a nivel sociológico era la religión mayoritaria en la España del momento. Dado que una parte considerable de la institución eclesiástica acabó vinculándose ideológicamente durante el conflicto y tras el mismo con el régimen resultante de la contienda, la religión se consolidaría como uno de los principales pilares del mismo, así como una de las justificaciones ideológicas de la sublevación y la guerra, desde prácticamente el inicio de la misma (Hernández Burgos, 2011; Rina, 2015).

La relación entre el catolicismo y la identidad nacional española, que iba a ser ampliamente promovida por el franquismo, es un fenómeno que ha sido denominado como «nacionalcatolicismo» y se trata de una corriente ideológica que ya constaba de un largo recorrido en la España contemporánea. Esta tendencia a asociar religión y Estado, y más concretamente la identidad del mismo con respecto al credo oficial y practicado por el común de la población, ahonda sus raíces en épocas anteriores, pero se consolida fundamentalmente durante el siglo XIX en el que diversos estados-nación, entre ellos el español, se configuran en su forma actual y buscan definirse con respecto a otros (Álvarez Junco, 2017; Rina, 2020a). Durante las primeras décadas del siglo XX esta tendencia ideológica se iba a ver afianzada entre los sectores conservadores 
y, en el plano institucional, especialmente durante la dictadura de Primo de Rivera (Botti, 1992; Montero, 2003; Callahan, 2007; Quiroga Fernández de Soto, 2007). Durante la etapa republicana los sectores conservadores de la sociedad española seguirían manteniendo esta visión frente a la laicidad del nuevo gobierno y las políticas en favor de la secularización del Estado, alcanzando su culmen durante la Guerra Civil en el bando sublevado y durante los años de posguerra.

El reflejo en la prensa falangista de Granada de las manifestaciones del nacionalcatolicismo y su relación con la celebración de la victoria franquista justo al finalizar la Guerra Civil van a ocupar este artículo, por lo que procedemos a mostrar de forma introductoria el sustento ideológico de dicho fenómeno que vincula, como hemos señalado, la religión católica con la identidad nacional española. Recomiendo la obra de Claudio Hernández Burgos sobre la «Cultura de la Victoria» en la Granada de posguerra (2011) para quienes deseen profundizar en los elementos convergentes y divergentes entre el discurso de la prensa católica (el diario Ideal en el caso granadino) y la falangista (el diario Patria, en cuyo discurso nos centraremos en esta ocasión). Más que en la descripción de los rituales, donde ambos suelen señalar los elementos tanto nacionalcatólicos como falangistas, es en el énfasis en determinados discursos en lo que se pueden hallar más divergencias. Si bien, a pesar de las divergencias y los desencuentros puntuales, tal y como señalan autores y autoras como Mónica Moreno Seco (2001) los conflictos entre el sector católico y el falangista no siempre fueron tan notables, al menos a nivel local, y la mayor parte de las ocasiones acabaron prevaleciendo los esfuerzos y los intereses comunes en apoyo del régimen.

Profundizando en la relación entre el nacionalcatolicismo y los fundamentos ideológicos del régimen franquista cabe destacar que este sentir nacionalcatólico, relativo al mencionado vínculo entre religión y nación, se iría abriendo camino entre algunos autores que reflexionarían sobre la situación del país en la época, y entre algunos sectores sociales especialmente conservadores (Moreno Seco, 2002). Durante los años siguientes al inicio del siglo XX el anticlericalismo y la tendencia iconoclasta se irían consolidando entre otros sectores sociales, que veían en la institución eclesiástica un impedimento para su progreso y un componente de la alienación de las clases populares (Delgado, 1992; Barrios Rozúa, 1995). Una vez iniciado el periodo republicano en 1931, estas dinámicas se agudizarían y se asociaría cada vez más la religión con un sector de la población, a pesar de suponer un elemento cultural común al conjunto de la sociedad española, y la propia institución se desvincularía a grandes rasgos del nuevo gobierno debido en gran medida a las actitudes 
iconoclastas que comenzarían a producirse poco después de la proclamación de la Segunda República y que el gobierno del momento no frenaría tal como ella esperaba. Las políticas en favor de una mayor laicidad del Estado serían otro motivo de desavenencias con la institución eclesiástica.

Por lo tanto comenzaría a perfilarse una visión dicotómica de la sociedad española, basada en la creación de alteridades conceptualizadas en torno al vínculo de una parte de la población con la religión y de otra parte con el ateísmo y la actitud anticlerical (Hernández Burgos, 2011; Rina, 2015, 2020b). Esta visión, que a nivel práctico resulta reduccionista como cualquier concepción dicotómica de la sociedad y que en tanto que una buena parte de dichas clases populares también participaba de las creencias católicas y llevaba a cabo prácticas religiosas relacionadas con las mismas (lo que comúnmente conocemos como religiosidad «popular» o religiosidad «tradicional»), funcionaría en tanto que permitía una clasificación social en creyentes, que por lo tanto eran considerados como conservadores y como representantes de la españolidad, y no creyentes o sujetos que se mostraban tibios ante la religión, que eran considerados como de escasa españolidad y pertenecientes a corrientes ideológicas subversivas de origen extranjero que podían poner en riesgo las «esencias» y la integridad de la nación. Esta visión simplista acarrearía consecuencias bastante graves para una parte de la población, la cual no siempre era reticente o no participaba de las creencias religiosas, una vez que estallara la Guerra Civil en 1936 y según dónde cada individuo se encontrara en el momento de la sublevación con la que ésta daría inicio.

En la retaguardia franquista la institución eclesiástica sería resarcida de la represión y la furia iconoclasta, llevándose a cabo un proceso que se ha denominado como «recatolización» del espacio público en las ciudades y pueblos españoles, proceso iniciado durante el conflicto y que se consolidaría en el conjunto del territorio nacional durante los años que lo siguieron, a partir de 1939 (Hernàndez i Martí, 2002; Mancha, 2018). La prensa iba a reflejar de forma amplia e insistente estos aspectos tanto de represión en una zona como de exaltación religiosa en otra, generando con ello una opinión pública deseada en torno a la relación entre el nuevo régimen y el resarcimiento de la institución eclesiástica en España.

El franquismo, que tendría desde los primeros momentos de la guerra el apoyo de la mayor parte de la Iglesia española, iba a fundamentar en buena medida su discurso triunfal en base a la defensa de la «civilización occidental» y de la fe católica. Las eucaristías, las misiones llevadas a cabo por frailes y monjas, los desfiles y procesiones y la enseñanza religiosa en las escuelas serían algunos elementos de reintroducción de la doctrina católica en la 
sociedad, tanto para reafirmar a los ya creyentes como para aleccionar a los que se consideraba debían volver al seno de la Iglesia. El fenómeno de la religiosidad popular, como ámbito vinculado a las prácticas culturales de las clases populares y que no resultaba ajeno tampoco a las élites locales, sería convenientemente instrumentalizado para hacer llegar el mensaje de la recatolización al común de la población y a aquellos sectores sociales que podían estar más vinculados política e ideológicamente a posturas contrarias al régimen, o que recelaban del mismo. Como fenómeno social y cultural que no siempre podía ser completamente controlado por la institución eclesiástica, éste sería vigilado en ocasiones por la misma para asegurar en la medida de lo posible el cumplimiento de la ortodoxia religiosa en manifestaciones devocionales como procesiones y romerías (Rina, 2015, 2020b).

La celebración masiva de ceremonias y rituales religiosos eclosionaría especialmente una vez ya finalizada la guerra, sirviendo para dar gracias a las fuerzas divinas por el final victorioso de la misma y para mostrar cuáles serían las pautas políticas del nuevo régimen en relación a los vínculos entre Iglesia y Estado. Estos rituales lograrían además cohesionar a la población en torno a la práctica religiosa, reforzar el vínculo entre identidad nacional y religión oficial, sacralizar y purificar de nuevo el espacio público y rendir culto a los caídos en la guerra que habían dado su vida "por Dios y por España», tal como ellos mismos promulgaban, en torno a las cruces erigidas en su memoria en casi todas las localidades (Hernández Burgos, 2011). Así, calles y plazas se convertirían en el escenario ideal para llevar a cabo el rezo colectivo de rosarios, las procesiones y cualquier tipo de manifestación pública de religiosidad y de festejo de la victoria franquista.

La celebración de estos rituales religiosos en el marco del nacionalcatolicismo y su vinculación con los festejos de la victoria franquista van a constituir la base del presente artículo en relación a la información que nos arrojan fuentes como las hemerográficas en el caso de la provincia de Granada, a la que nos acercaremos a través de la prensa histórica como parte de la memoria de dicha época. Nos centraremos en el año en que finalizaría la Guerra Civil y se iniciaría la posguerra, es decir en 1939, el denominado como «Año de la Victoria», y en las páginas del diario Patria, el diario falangista de Granada, para observar el tratamiento en la prensa del régimen (lo que vendría a denominarse poco después como «Prensa del Movimiento»), de las muestras del nacionalcatolicismo y su vinculación con la religiosidad y la organización de ceremonias religiosas en esta provincia, que podemos enmarcar dentro de la denominada como «Cultura de la Victoria» sobre la que se iba a sustentar la 
ideología del régimen durante los años siguientes ${ }^{1}$. La ley de prensa de 1938, cuyas medidas seguirían vigentes durante décadas, consagraba el ejercicio periodístico en la España franquista al servicio del Estado (es decir a la labor propagandística del régimen) e imponía un férreo control a las publicaciones mediante la censura, a fin de evitar visiones desviadas en exceso de la perspectiva oficial. La propaganda sería uno de los principales pilares en la difusión de dicha ideología entre la población, por lo que la prensa nos puede resultar de gran ayuda para acercarnos a este fenómeno.

\section{Festejar el «Año de la Victoria»: la propaganda y el discurso oficial del régimen}

El año 1939 supone la conclusión de un conflicto que había durado casi tres años y que finalizaba con la victoria del bando que se había sublevado contra el gobierno republicano en julio de 1936, lo que constituiría un golpe de estado que en lugar de transcurrir sin demasiados incidentes, como había sucedido en anteriores ocasiones, desembocaría en una contienda civil. España se sumaba, así, a la tendencia hacia los regímenes autoritarios que había hecho irrupción en la Europa de entreguerras durante la década anterior y que la conectaba por tanto con los regímenes europeos que formaban parte del Eje (Italia y Alemania), aunque con evidentes características propias. La relevancia otorgada a la religión católica, la practicada por gran parte de la sociedad y la que se consideraba como unida indivisiblemente a la identidad nacional española y a su esplendor en tiempos pasados, sería decisiva en la búsqueda de apoyos y en la consolidación de la nueva situación política del país.

Uno de los elementos principales de la propaganda durante la guerra iba a ser la «liberación» (la toma u ocupación) de pueblos y ciudades aún durante los últimos días de la contienda, que concluiría con la firma del último parte de guerra por parte de Franco como Jefe del Estado y Generalísimo de los ejércitos en la ciudad de Burgos el día 1 de abril de 1939. El diario Patria de Granada, representante a nivel provincial de la prensa falangista (lo que más adelante se conocería como Prensa del Movimiento), muestra en su primera página al día siguiente el titular «iLa guerra ha terminado!» junto con el parte de guerra, una fotografía del Caudillo y el lema «Franco, Franco, Franco». Resulta de interés comprobar cómo, a pesar de la finalización como tal de la lucha en el campo de batalla (aunque la guerrilla antifranquista continuaría su actividad hasta bien entrado el régimen), el diario llamaba tan sólo dos días después a los españoles a estar alertas contra el enemigo. Así pues, se reforzaba la idea

1. El diario Patria sería fundado en 1935 y se publicaría hasta 1983. 
de que los supuestamente vencidos en la guerra podían seguir suponiendo una amenaza para los vencedores, y que por lo tanto se debía vigilar cualquier tipo de actitud considerada subversiva. El régimen vigilaría además cualquier forma de festejo o de manifestación cultural que se considerara subversiva, como el caso del carnaval, que sería incluso prohibido aunque dicha prohibición no se cumpliera siempre (Román Ruiz, 2020). La prensa se encargaba de recordar con cierta regularidad dichas prohibiciones.

La Dirección Nacional de Prensa y Propaganda, el organismo oficial del régimen que se encargaba de controlar y llevar a cabo la difusión propagandística de los mensajes del mismo, fue creada en 1937 como órgano dependiente de FET y de las JONS, agrupando los diversos medios de comunicación de inspiración falangista una vez producida la unificación de FE de las JONS con los requetés, y en 1938 pasaría a formar parte de la administración del Estado. Los diversos diarios que conformarían la Prensa del Movimiento dependían de dicho organismo, el cual perviviría hasta la disolución del Movimiento Nacional en 1977. De esta forma, el régimen se hacía con el control de buena parte de la prensa del país (a la que habría que sumar la prensa de inspiración católica, como el diario Ideal en la provincia de Granada, que mostraba un discurso también oficial aunque con una visión no tan sumamente nacionalsindicalista sino más nacionalcatólica), y de esta forma podía controlar la retórica revolucionaria del discurso falangista, mostrando además a la población la visión que se deseaba de la realidad, tanto nacional como extranjera (Delgado Idarreta, 2004).

La adaptación de los diarios locales, provinciales y regionales a los intereses propagandísticos del nuevo régimen comenzaría a configurarse durante la propia guerra, como en el caso que nos ocupa, y se trataba de responder a las consignas promulgadas desde el poder oficial que se estaba consolidando, en especial al mensaje victorioso y a las menciones constantes a la figura del Caudillo y a la idea de la salvación de la Patria (Castro, 2020). Los diarios solían constar de diversas secciones dedicadas al trancurso de la guerra, a la recuperación de las festividades y ceremonias religiosas, a las actividades y viajes llevados a cabo por Franco y a la labor llevada a cabo por las organizaciones vinculadas al Movimiento, dependientes fundamentalmente de FET y de las JONS, como las organizaciones juveniles, la Sección Femenina y Auxilio Social. Durante la contienda las proclamas de los principales artífices de la sublevación, incluido el propio Franco, así como las de requetés y falangistas, iniciaban las primeras páginas de los diarios, y a partir de 1939, el «Año de la Victoria», en el que nos centramos en esta ocasión, el mensaje triunfalista alcanzaría su culmen (Zalbidea, 2005). 
En cuanto a lo que algunos autores han denominado como «Cultura de la Victoria» (Hernández Burgos, 2011), que sería aquella que se impondría una vez finalizada la guerra, ésta sería reflejada intensamente en la prensa, y podemos también rastrearla a través de los testimonios orales e incluso de la filmografía (películas como Raza, ya en 1941, y otras de corte militar y falangista). Esta cultura, o estas prácticas culturales, que pueden ser analizadas desde una perspectiva histórica y socioantropológica, se refieren al hecho de la victoria del bando franquista como un elemento que alcanza dimensiones míticas, donde el relato histórico se funde con el legendario, que rinde culto a héroes, conocidos o anónimos (Calvo Sotelo como primer «mártir» de la causa, José Antonio Primo de Rivera como mártir y caído por antonomasia, Ramiro Ledesma, Onésimo Redondo, así como los caídos en general tanto en la retaguardia como en el frente de batalla), y en cuyo homenaje se levantarían monumentos y cruces en numerosos municipios (Box, 2004).

La dimensión mítica de la victoria tendría su propio mito de origen, la sublevación del 18 de julio en este caso, que sería concebida como el inicio del proceso de liberación nacional, un liderazgo carismático en la figura del general Franco, como líder y guía espiritual de los «cruzados» por Dios y por la Patria, y toda una retórica, bastante barroquizante en ocasiones, proveniente sobre todo del elemento falangista, de la que la letra de su himno, el «Cara al Sol», es una buena muestra. La idea de una España que iba a renacer y donde florecería una nueva primavera, lo cual coincidiría además con el hecho de finalizar la guerra en el mes de abril, genera una visión de la guerra como proceso ritual de purificación del suelo patrio y como un ritual de paso hacia un nuevo Estado.

Acercándonos a la dimensión ritual, sobre la que más adelante profundizaremos en relación al ámbito de la religión, cabe destacar precisamente el culto a los caídos, del que los falangistas serían firmes defensores a lo largo del régimen, y que iba a ser fundamental para consolidar la cultura de la victoria durante los primeros años de posguerra, en torno a elementos conmemorativos que seguían una tendencia existente en Europa desde la Primera Guerra Mundial, como los dedicados a la memoria de los caídos, y que permitían un mayor vínculo entre los mismos y la opinión pública de la población (Massa, 1998). Este culto, verdadera veneración coletiva hacia los fallecidos durante el trancurso del conflicto, se iba a ver materializado a través de la erección en casi todas las localidades de cruces de piedra en su memoria, placas con sus nombres en las paredes de las iglesias, monolitos y obeliscos. Estos lugares suponían espacios adecuados para la realización de los rituales conmemorativos, especialmente 
cada 20 de noviembre, en que se recordaba el día del fusilamiento del fundador de Falange.

El ritual de culto a los caídos solía desarrollarse en torno a las cruces dedicadas a su memoria, saludando con el brazo en alto y repitiendo los gritos de ritual (así son denominados en la misma prensa) de «iPresentes!», « ¡Arriba España!» y vivas a Franco. Muchos de los asistentes solían lucir la camisa azul, y a partir del estallido de la guerra Falange, que previamente había sido un grupo político con aspiración a convertirse en un partido de masas pero que no lo había sido como tal, comenzaría a ver engrosadas sus listas con muchos nuevos afiliados y afiliadas. Los afiliados pasarían a pertenecer a las jerarquías del partido y las afiliadas a las de la Sección Femenina. Auxilio Social, institución fundada al inicio de la guerra como medio de aprovisionamiento y socorro de los soldados y de los habitantes de la retaguardia franquista, quedaría vinculada a la Sección Femenina y continuaría con su labor durante los años de posguerra, estableciendo sus locales en numerosos municipios (Rodríguez López, 2010). El régimen intentaría ganar adeptos mediante la labor de dichas instituciones a lo largo de la geografía nacional, ayudando a la generación del deseado consenso entre la población en torno a las políticas del nuevo Estado (Molinero, 2005).

La afiliación a las instituciones vinculadas a Falange, el partido oficial (a partir de 1937 denominado FET y de las JONS), así como a instituciones de carácter católico como Acción Católica, con grupos de juventudes y de afiliados y afiliadas, supondrían un incremento de los apoyos sociales al régimen, el cual ya contaba con sectores de la población a favor desde el inicio de la guerra, que consideraban que la situación del país debía ser reconducida en virtud de valores tradicionales, entre los que se encontraba la relación entre religión e identidad nacional, los cuales serían retomados, e incluso sobredimensionados, durante los años posteriores (Cobo, 2015). El caso que nos ocupa en esta ocasión, el del diario Patria, nos muestra dicha relación como veremos más adelante. La prensa falangista constaba de numerosos diarios por toda la geografía española, lo que permitiría que el régimen pudiera hacerse con un mayor control del ámbito periodístico a nivel nacional, control al que habría que añadir la imposición de la censura y el papel de elementos falangistas y católicos en dicha vigilancia de los medios de comunicación.

\section{Patria y credo: ceremonias y rituales de la victoria}

En las localidades que habían estado situadas en zona sublevada desde el inicio de la guerra, la religiosidad se había visto puesta en valor y garantizada por las autoridades municipales (Barrios Rozúa, 2008). Este sería el caso de la 
capital granadina, en contraste con la mayor parte de la provincia, que caería en manos de las tropas franquistas a lo largo de 1937 (caso de la mayor parte de la costa) y 1938 (caso de las comarcas del norte de la provincia, Guadix, Baza y el Altiplano), e incluso durante los últimos días del conflicto, en que serían tomadas localidades alpujarreñas y costeras situadas en el extremo oriental de la provincia, y cuya toma sería ampliamente mostrada en la prensa como colofón a la victoria definitiva. Las celebraciones de la victoria iban a marcar el ciclo festivo anual, con los elementos nacionalcatólicos mezclados en numerosas ocasiones con los tradicionalistas, militares y falangistas, quedando las manifestaciones religiosas populares al servicio del mensaje del régimen recién iniciado, como veremos siguiendo cronológicamente las celebraciones del año 1939 tanto en la capital granadina como en la provincia. Veremos cómo diversas formas de ritualidad iban a ser instrumentalizadas, algunas con un marcado carácter religioso (eucaristías, procesiones, rosarios), otras religioso y a la vez popular e identitario (cruces de mayo, romerías, fiestas patronales), y otras más político (Fiesta de la Victoria, 18 de julio, conmemoración de la Guerra de la Independencia, reposición del crucifijo en las escuelas, culto a los caídos).

Granada comenzaba a estrenar la nueva victoria con una amplia celebración de procesiones y ceremonias de culto devocional, especialmente hacia su patrona, la Virgen de las Angustias. Se retomaba de esta forma su culto tras los años de guerra y se le daba gracias por la victoria. El ayuntamiento iba a celebrar cada Viernes de Dolores a partir de entonces el voto de la ciudad ante su patrona, por haberla salvado durante los años de la guerra de asedios y bombardeos. La devoción a la Virgen de las Angustias, la principal en la capital y muy relevante en los pueblos aledaños, suponía una forma de vinculación entre el nacionalcatolicismo y la identidad local. La imagen recibiría también honores militares por su supuesta protección de la capital y de los granadinos durante la guerra, y se le bordaría un manto dedicado a los alféreces granadinos caídos en el campo de batalla que sería entregado al año siguiente (Hernández Burgos, 2011; Rina, 2020b). El fervor y la ritualidad en homenaje a la patrona serían aspectos ampliamente señalados tanto en la prensa católica provincial como en la falangista. Así consta en el diario Patria:

Granada rinde homenaje a su patrona.

El domingo, las campanas cantaron la más jubilosa de sus canciones, y el aire se pobló de cálidos aplausos, de vivas emocionados, de alegre cohetería que rompió el intenso azul de la tarde con los trazos de sus palmeras luminosas. La Virgen de las Angustias, nuestra Virgen, volvía a visitar las calles granadinas después de tantos meses de recogimiento, y la muchedumbre, delirante de amor, supo expresar a su paso todo el hondo fervor acumulado en horas 
de incertidumbre intensa, vividas con el pensamiento reconcentrado en ella, única guía y consuelo en los días afanosos de lucha y de liberación. ${ }^{2}$

Entre el entusiasmo y fervor de Granada, la Virgen de las Angustias regresó triunfalmente a su Basílica.

Por la mañana el Arzobispo dirigió en la Catedral una plática a los fieles.

El pasado domingo, último del solemne septenario ofrecido por Granada a su Amantísima Patrona, la Virgen de las Angustias, con motivo del final glorioso de la guerra de la liberación de España, se celebró en la Santa Iglesia Catedral una solemne Misa oficiada por el Excelentísimo y Reverendísimo Sr. Arzobispo. [...] El hermoso templo aparecía profusamente iluminado y con gran número de fieles. En los sitiales de costumbre tomaron asiento los gestores municipales presididos por el Alcalde, camarada Gallego y Burín; diputados provinciales presididos por el Presidente de la Diputación accidental, camarada Figueroa y Delegados Provinciales de Falange Española Tradicionalista y de las JONS, presididos por el Jefe provincial, camarada Prieto Moreno. ${ }^{3}$

El Cristo de los Favores, situado en el barrio del Realejo de la capital y de gran devoción entre los habitantes de la misma, iba a ser también ampliamente venerado, siendo receptor de multitud de promesas que se llevaban a cabo en el marco de grandes manifestaciones de devoción y a modo de acción de gracias por la victoria en la guerra. La imagen de Cristo iba a ser asimilada a la del cuerpo sufrido de la Patria, que había sido ultrajado por sus supuestos enemigos y que ahora era redimido y se le rendía el culto que merecía (Hernández Burgos, 2011). A sus pies se colocaban numerosas ofrendas, al igual que se ofrendaban a la Patria y a los caídos por ella coronas de flores y la cruz los representaba. La instrumentalización de los elementos de la identidad local, especialmente la religiosidad y los rituales, por parte del régimen, supondría una clave en la búsqueda de apoyos sociales entre la población y una forma de enraizarse aún más entre la opinión pública de la misma (Rina, 2015). De esta forma, al culto «tradicional» de las imágenes religiosas se sumaba el entramado ritual propio del nacionalcatolicismo y de las conmemoraciones de la victoria del 1 de abril de 1939, que iban a marcar todo dicho año y las festividades celebradas a lo largo del mismo.

Ante el Cristo de los Favores, hizo ayer Granada las tres peticiones.

Emoción de la hora. Emoción del día. Tres de la tarde del viernes. Las alas se han quedado paradas y la brisa quieta. [...] Granada salió ayer a la calle apresuradamente para asistir al culto que se celebra en el Cristo de los Favores anualmente. El agua no ha impedido que asistan a hacer las Tres Peticiones mujeres y hombres de Granada. Todos han ido a contar sus cuitas al Cristo.

2. Patria, 11/04/1939, pág. 1 .

3. 18/04/1939, pág. 2. 
Pocos momentos antes de las tres llegó al Campo del Príncipe la imagen de Nuestra Señora de la Soledad. La Madre se encontraba con el hijo en su momento de su mayor dolor. Al sonor la hora grave en que expiró el Salvador, toda Granada se postra ante la Imagen Venerable, haciendo sus peticiones y dando gracias al Salvador por la salvación de nuestra Patria. ${ }^{4}$

El 1. ${ }^{\circ}$ de abril se celebraba en la localidad de Guadix una misa de campaña, reforzando el vínculo entre los elementos eclesiásticos y militares. Dicha misa tendría lugar en la plaza porticada situada frente a la Catedral, conocida popularmente como «Plaza de las Palomas», que había sido muy dañada durante la guerra y que sería reconstruida por el Servicio Nacional de Regiones Devastadas. La celebración de rituales religiosos y de carácter militar y falangista en las inmediaciones de los edificios y espacios damnificados durante la contienda serviría como elemento de propaganda para mostrar los desmanes de las «hordas marxistas» y cómo dichos espacios iban a ser resignificados y purificados para servir a los valores de los vencedores, suponiendo un escenario aleccionador para mostrar cómo el régimen devolvía a su antiguo esplendor y dignificaba lugares que habían quedado prácticamente en ruinas (Barrios Rozúa, 2008). Guadix, junto con su comarca, habían pasado a manos franquistas a partir de 1937, habiendo sido, junto con Baza, un importante núcleo de actividad revolucionaria durante el control republicano.

Mención aparte puede hacerse de la presencia de algunas personalidades del régimen en determinados momentos de ritualidad tanto relativa a la victoria como a la religión en sí, como es el caso de la Semana Santa o el culto a los caídos, con una visita en el propio abril de 1939 del general Millán Astray a una misa en memoria de los caídos celebrada en la Capilla Real de la Catedral de Granada, así como la presencia del general Queipo de Llano, que había dirigido la sublevación y la guerra en Andalucía. La asistencia de personalidades relevantes del régimen cumplía la función de vincular a la población local con los representates del mismo, y las arengas de éstos recordaban el carácter bélico del triunfo y de la restitución del «orden» en la vida cotidiana de los españoles. El propio Franco, en su primera visita a Granada tras la victoria ese mismo año, rendiría culto a la patrona de la ciudad y asistiría a diversos actos religiosos (Hernández Burgos, 2011; Rina, 2020b).

Un elemento festivo muy del gusto de los granadinos, que supone una fecha relevante en el calendario anual y que sería promovido por el régimen serían las Cruces de Mayo, de gran tradición y que serían revitalizadas tras la guerra (Hernández Burgos, 2011). Tanto en la capital como en los pueblos de la

4. 08/04/1939, pág. 2. 
provincia la costumbre era, y continúa siendo, situar diversas cruces elaboradas con flores y decoradas con objetos de cobre y cerámica en múltiples puntos de la localidad, organizándose concursos y concediéndose premios a las más vistosas. A pesar de las estrecheces del momento, las élites del régimen hacían gala de generosidad concediendo la financiación para los propios premios, consiguiendo así generar una idea de una cierta bonanza y de apoyo de las mismas a las fiestas populares y a mejorar la economía de los vecinos, a la vez que se incidía en la labor de revitalización de dichos rituales festivos que, una vez finalizado el conflicto en el conjunto del territorio nacional, podían volver a ser celebrados con un renovado esplendor que enmendaba los actos de iconoclastia y la persecución religiosa previa, dando así la percepción de que la tradición se erigía sobre las ruinas y se ponía al servicio de la renovación y reconstrucción de la nación. Este tipo de fiestas suponían además una buena ocasión para mostrar las obras de beneficencia llevadas a cabo por las instituciones del régimen, como Auxilio Social, que tras las celebraciones ofrecían comidas a los asistentes, especialmente a los niños de las escuelas. Las autoridades locales eran en otras ocasiones las que se encargaban de gestionar dichos momentos de comensalidad que creaban una sensación de cierta opulencia, más simulada que real, y que era administrada y debida a la labor de las fuerzas vivas, vinculadas a FET y de las JONS y a elementos militares. Dado que el régimen se encargaría de achacar la escasez de posguerra no a sus propias políticas sino a la situación derivada de la guerra, no sería difícil hacer de estos momentos un espacio de comunión de los vecinos con las políticas oficiales y con la noción de vuelta a las prácticas religiosas católicas o de recatolización de la vida nacional.

El Ayuntamiento concederá premios para las mejores Cruces de Mayo.

Ayer celebró sesión ordinaria la Comisión Municipal Permanente, bajo la presidencia del Alcalde. Se acordó, para el mayor esplendor de la fiesta de la Cruz de Mayo, conceder un premio de 150 pesetas, dos de 100 y tres de 50, a las mejores cruces que se erijan el día 3 de mayo. ${ }^{5}$

El día de la Cruz revestirá este año inusitado esplendor.

Pasan de veinte las inscritas en el Ayuntamiento que aspiran a premio. Bandas de música serán enviadas a los barrios más populosos. Es extraordinaria la animación que existe para celebrar mañana el día de la Cruz, en Granada. Al requerimiento del Ayuntamiento ha respondido como nunca la ciudad y son numorosísimas las cruces que se están levantando en distintos lugares de la misma. El Municipio enviará bandas de música a los barrios más populosos, y la del Ayuntamiento actuará en la Plaza del Carmen ante la Cruz Monumental allí erigida por él en la tarde y noche del citado día. ${ }^{6}$

5. 27/04/1939, pág. 4 .

6. 02/05/1939, pág. 5 .

Pasado y Memoria. Revista de Historia Contemporánea, 24, 2022, pp. 239-266 
Ugíjar. La festividad de la Cruz.

Ugíjar, corazón y capital de la Alpujarra ha celebrado la fiesta de la Cruz con un esplendor desconocido en la comarca. El Teniente Coronel Jefe Militar de la Zona don José Nestares ofreció cinco valiosos premios en metálico para las mejores cruces que se instalaran en sus calles, y desde la víspera, infinidad de jóvenes del pueblo se dedicaron a formar bellos altares con los más vistosos elementos decorativos y verdadera profusión de flores. Mantones, colchas, tapices, cobres, cerámicas y multitud de hermosísimas prendas engalanaban el pueblo, presentando magnífico aspecto. En la madrugada del día de la Cruz salió el Rosario y de mañana se dijo en la plaza mayor ante las ruinas de la iglesia destruida por las hordas rojas, una solemne misa a la que asistieron los mandos militares, autoridades locales y pueblo en masa. Se dio comida extraordinaria y dulces a la tropa de guarnición y en los comedores de Auxilio Social. ${ }^{7}$

Un aspecto a destacar de la visión moral y de la concepción agrarista del nuevo régimen se manifestaba a través de rituales como la bendición de los campos, como tenemos noticia que sucedía en la localidad de Huéscar, al norte de la provincia, en la que los vecinos renovaban su vínculo con la tierra que los alimentaba y el régimen se procuraba apoyos sociales entre el campesinado. El culto a aquellos santos vinculados a la producción agrícola y ganadera tendrían una especial relevancia y a través de dicho culto se reafirmaban los lazos identitarios del pueblo con respecto a las advocaciones patronales, y del régimen con la religiosidad popular propia de la cultura de las zonas rurales a través de la presencia de las autoridades del mismo en las procesiones y demás rituales festivos (Rodríguez Becerra, 2000). La Semana Santa supone un capítulo aparte en sí mismo, ya que aunque no se trata de un ritual festivo de carácter patronal se halla inserto en la identidad local y sería también uno de los más instrumentalizados tanto durante la guerra como al término de la misma para mostrar la relación entre el nacionalcatolicismo y el nuevo Estado (Richards, 2010; Rina, 2015, 2017, 2020b; Vincent, 2017). De igual modo iba a suceder con la festividad del Corpus Christi, principalmente en la capital granadina como forma de celebrar la victoria, dada su importancia en el marco festivo local (Hernández Burgos, 2011). Mención especial merece también la procesión del Cristo del Paño de Moclín, una de las imágenes de mayor devoción en la provincia de Granada y en el conjunto del área oriental andaluza, por las calles de la capital granadina en octubre de 1939, portado por vecinos de la localidad de Moclín, a cuyo paso se dieron amplias muestras de la veneración hacia el mismo (Hernández Burgos, 2011). Las imágenes más veneradas en las localidades recibían culto en misas en acción de gracias,

7. 09/05/1039, pág. 6 .

Pasado y Memoria. Revista de Historia Contemporánea, 24, 2022, pp. 239-266 
ya que se consideraba que habían ayudado, como en el caso de la patrona de Granada, a la victoria y habían guiado las decisiones de Franco y salvaguardado a las tropas. En pueblos como La Zubia se rendía culto a la imagen de Nuestro Padre Jesús como consta:

La Zubia. Función religiosa en honor de Nuestro Padre Jesús.

El día 23 del pasado mes de abril y con extraordinaria solemnidad y fervor nunca igualado en los anales religiosos de este pueblo, se ha celebrado una función a Nuestro Padre Jesús en acción de gracias por la terminación de la guerra. Aunque la iniciativa de esta solemne misa partió del típico barrio del Molino, puede decirse que tomó parte en ella todo el pueblo de La Zubia, siendo insuficiente el templo parroquial para albergar a tantos devotos. [...] Su disertación [del párroco] tuvo como tema fundamental el drama del Calvario y la protección tan señalada de Nuestro Padre Jesús que ha sabido iluminar a nuestro invicto Caudillo para llevarnos a la victoria final. Su palabra fue escuchada con verdadero fervor y sobre todo al final tuvo frases tan hermosas que hicieron brotar las lágrimas. Dio vivas a Nuestro Padre Jesús, al Generalísimo y a España, que fueron contestados por el pueblo con entusiasmo. ${ }^{8}$

La utilización repetida de elementos de la Historia de España para generar una idea de continuidad entre acontecimientos del pasado de carácter patriótico y del presente, especialmente aquellos que habían tenido lugar durante las primeras décadas del siglo XIX, sería habitual en los primeros años de posguerra. Nada más acabada la misma, la Guerra de la Independencia, uno de los principales hitos de la historia decimonónica española, comenzaría a ser ampliamente ensalzada y se crearían nuevos rituales para conmemorarla, junto a los ya existentes (Di Febo, 2002; Hernández Burgos, 2011). La unión de las celebraciones de carácter patriótico con las de carácter religioso haría que la celebración del 2 de mayo, anteriormente más marcadamente civil, se combinara con el ritual eclesiástico del cumplimiento pascual, como en el caso que aquí observamos de la localidad de Cúllar Vega. Rememorar los fusilamientos de patriotas del pasado a manos de fuerzas invasoras extranjeras podía ser utilizado en el discurso oficial para crear la sensación de que la Guerra Civil había sido fundamentalmente una «guerra de liberación», tal como se había propagado en la prensa y los medios de comunicación del régimen, y que los verdaderos patriotas habían sido fusilados y habían combatido contra los enemigos de la patria, los cuales habrían sido inspirados por el marxismo (concebido como una ideología extranjera y contraria a la tradición y a los intereses de la patria) y especialmente por su vertiente soviética, claramente extranjera y que buscaba acabar con el orden establecido a través de reformas

8. 03/05/1939, pág. 6 . 
estructurales que pudieran hacer peligrar la integridad política y moral de la nación. Sería el sector militar de las fuerzas vivas el que celebrara con más intensidad este tipo de rituales dedicados a conmemorar los hitos del pasado, como en este caso.

Coincidiendo con la fiesta nacional del 2 de mayo, día de triunfo para España, que celebra una de las fechas más gloriosas de su Historia Patria, día memorable en el que el sentimiento de independencia prendió como una oleada de fuego en los corazones de todos los españoles, ha tenido lugar en Cúllar Vega el acto del cumplimiento Pascual de la segunda compañía del octavo Batallón de Trabajadores, que manda el alférez don César del Campo Díaz. ${ }^{9}$

Uno de los rituales más significativos de lo que supuso la construcción de la cultura de la victoria era en efecto la «Fiesta de la Victoria», celebrada el día 18 de abril de 1939 en la capital granadina. Con motivo de dicha celebración se llevaría a cabo una romería y se convocaría un concurso de carretas, para premiar a la más vistosa de todas. El hecho de celebrar un ritual festivo religioso de este tipo, es decir una romería, considerado como típicamente andaluz (en esta versión con carretas engalanadas que recuerda a las grandes romerías andaluzas) entronca con la visión tipista del régimen, que entendía el costumbrismo como un elemento cultural cercano a las clases populares y que podía hacer que la doctrina religiosa se vinculara a la religiosidad popular y a su dimensión festiva, y así introducir más fácilmente el mensaje de la victoria. La romería, al ser un momento de reunión de gran número de devotos y suponer un espacio para la comensalidad entre los miembros de la comunidad, podía utilizarse para prodigar el mensaje de acción de gracias por la victoria de los sublevados y la conclusión de la guerra. Al ensalzar el tipismo andaluz a través de la propia romería y de las carretas, la victoria quedaba así vinculada a la cultura autóctona a través de este tipo de celebraciones festivas. El tipismo, vinculado en cierta medida a la identidad de cada territorio, podía ser instrumentalizado dado que contribuía a la visión de España como un Estado basado en su unidad territorial pero con peculiaridades que otorgaban una sensación de diversidad folklórica a la cultura nacional como conjunto (Ortiz García, 1997).

La Fiesta de la Victoria. Granada la celebrará con una gran romería a la Cuesta de las Cabezas.

El próximo día 18, tendrá lugar en Granada, con motivo de las festividades de la victoria, una romería típica andaluza y peregrinación popular a las fundaciones de la Cuesta de las Cabezas. En la mañana de dicho día las carretas presentadas después de examinadas por el jurado convocador del concurso, desfilarán por las principales vías de la población, saliendo seguidamente para

9. 05/05/1939, pág. 6 . 
la Cuesta de las Cabezas. En el trayecto, se preparan en las principales ventas agasajos a los participantes en la comitiva de carretas andaluzas, que hará varias paradas en el trayecto para llegar a la Cuesta de las Cabezas sobre las cinco de la tarde, hora en que comenzará esta fiesta de tan honda significación para conmemorar una Victoria obtenida a precio de sangre y heroismo. ${ }^{10}$

La Fiesta de la Victoria sería celebrada también, en consonancia con el nacionalcatolicismo, mediante las eucaristías. En la catedral granadina se realizó una misa en acción de gracias por el triunfo de las tropas sublevadas y por la protección que había sido otorgada a la ciudad durante la guerra. Al tener lugar en el principal templo de la ciudad se aseguraba la plena solemnidad de tal acto, así como el espacio necesario para albergar a la mayor cantidad de asistentes posible. Las autoridades encabezaban la celebración de la eucaristía, mientras que la misma quedaba consagrada a la nueva ritualidad a través de la presencia como escoltas del altar mayor de las juventudes falangistas, quedando así el Movimiento Nacional representado junto con las fuerzas vivas locales. Aunque la prensa no suele mencionar la cuestión, a fin de no generar una percepción de falta de cohesión entre los diversos elementos que sustentaban el régimen, cabe destacar que en ocasiones los máximos representantes locales del clero, como los arzobispos, recelaban de la excesiva conjunción entre simbología y ritualidad falangista y celebraciones y ritos católicos. Así, aspectos como el saludo brazo en alto a las imágenes devocionales a su paso por las calles o los gritos de exaltación de los sublevados no siempre eran bien vistos ya que se consideraban como elementos más paganos que católicos (en parte el propio fascismo era concebido como un movimiento más pagano que basado en la fe), por lo que el clero pretendía que su visión nacionalcatólica prevaleciera sobre la falangista y pedía que no se hicieran tales manifestaciones de inspiración fascista durante los actos religiosos. Tal era la visión de arzobispos como el Cardenal Segura en la diócesis sevillana o el Cardenal Parrado en la granadina, quienes preferían una manifestación más marcadamente católica, sin brazos en alto y gritos rituales de carácter fascista en las procesiones (Rina, 2015, 2017, 2020b). A pesar de ello, y en un año tan simbólico para las diversas facciones que componían el nuevo régimen como fue 1939, en que concluía la guerra que había dado origen al mismo, la relación entre falangismo y nacionalcatolicismo sería más promovida, y la prensa falangista daría buena cuenta de ello.

La Fiesta de la Victoria. Misa en acción de gracias por el Triunfo de nuestras Armas.

Ayer a las once se verificó en la Santa Iglesia Catedral Metropolitana la Misa de la Victoria en acción de gracias por la feliz terminación de la guerra. Momentos

10. 12/05/1939, pág. 7 . 
antes de la hora indicada llegaron la autoridades que fueron recibidas por una comisión de la Catedral. [...] Daban escolta al altar mayor una sección de cadetes de la Organización Juvenil. ${ }^{11}$

En el caso de las fiestas patronales, como hemos señalado, nos hallamos ante un fenómeno cultural que suponía una ocasión ideal para imbricar la identidad local con la nacional a través de la relación entre nacionalcatolicismo y religiosidad popular y especialmente con los rituales propios del régimen, como las manifestaciones de la cultura de la victoria y los himnos. Los párrocos, en calidad de autoridad eclesiástica en los pueblos, tendrían un papel sumamente relevante en cuanto a este cometido, como puede verse:

Pinos del Rey (actual Pinos del Valle). Los cultos del Santísimo Cristo del Zapato.

Según se tenía anunciado por este diario y por numerosos programas que han llevado a muchos puntos tan grata nueva, se han celebrado con toda solemnidad los cultos al Santísimo Cristo del Zapato, respondiendo a la iniciativa de nuestro querido cura párroco [...] La madrugada del día 3, deseosos los vecinos de demostrar su júbilo salieron a cantar el «despertador» del Rosario de la Aurora acompañando de campanillas a la letra graciosa e ingenua de las coplas. Inmediatamente salió el pueblo en masa a sacar el Rosario que procesionalmente recorrió todas las calles del pueblo, cantando las glorias de María, escoltando con sus banderolas adornados de flores y sus farolillos, la Imagen del Cristo, llevado por los flechas en andas primorosamente adornadas. [...] Por último, don Francisco García [el párroco] invitó a todos a seguir una recta conducta después del ejemplo de la juventud que derramó su sangre por hacer una España mejor. No olvidó a los Caídos y estas palabras fueron escuchadas con toda emoción prorrumpiéndose en estruendosos aplausos, dándose muchos vivas y cantándose el «Cara al Sol» y otros himnos patrióticos, repartiéndose el público por diversos puntos a saborear sus meriendas. ${ }^{12}$

Uno de los principales objetivos del régimen iba a ser vincularse a través de sus organizaciones con el conjunto de la población. El papel de Falange, como partido único (unido como se ha señalado por decreto de Franco a los requetés en 1937 y al que se unirían durante la guerra los miembros de otros partidos y organizaciones que simpatizaban con la sublevación), y debido al incremento de afiliados durante el conflicto y al finalizar el mismo, ya fuera por convencimiento político o por asegurarse un reconocimiento y un modo de salvaguarda, iba a ser fundamental en los momentos de comunidad entre los vecinos y las muestras locales de devoción, como en el caso que observamos a continuación. La simbología falangista, especialmente el yugo y las flechas

11. 20/05/1939, pág. 2.

12. $14 / 05 / 1039$, pág. 6 .

Pasado y Memoria. Revista de Historia Contemporánea, 24, 2022, pp. 239-266 
como la más característica, iba a inundar las celebraciones religiosas y a ser mostradas en honor a las imágenes veneradas. De nuevo en esta ocasión las juventudes falangistas o «flechas» harían acto de presencia con sus propias formas de ritualidad y sus uniformes. De nuevo, también, la relación entre la identidad local en base a la devoción compartida y la ritualidad falangista.

Ante el Cristo de la Era la Falange y el pueblo de Pulianas rindió fervorosa gratitud.

En la mañana del pasado domingo se celebraron en el vecino pueblo de Pulianas varios actos como homenaje de gratitud de los vecinos de dicho pueblo hacia el venerado Cristo de las Eras por haber librado en la pasada guerra a cuantos hijos de Pulianas lucharon glorosiamente en ella. Al pie de la sagrada imagen se levantó un artístico altar, cubierto de numerosas plantas naturales. Un yugo y flechas se había colocado al pie del Cristo y las banderas de España y de la Falange completaban el exorno. El Santo Sacrificio de la misa fue oficiada por el cura párroco, don José Tovar Castilla asistido de dos flechas de nuestra Organización Juvenil. ${ }^{13}$

Además de los festejos de la propia victoria, la fecha más relevante del calendario del régimen iba a ser el 18 de julio, la cual sería conmemorada anualmente y que en 1939 iba a revestir un especial significado debido a ser el «Año de la Victoria». La conmemoración de la jornada de la sublevación (el «Alzamiento Nacional») comenzaría con una función religiosa en acción de gracias por el triunfo de la sublevación en Granada y por la victoria, rindiendo homenaje a continuación a las tropas sublevadas en la ciudad en los primeros días de la guerra, y culminando con un acto ante la cruz erigida en homenaje a los caídos. Este y los siguientes años serían los de más ferviente celebración de los rituales vinculados a la guerra, tanto a la sublevación como a la victoria, que seguirían siendo celebrados ya sobre todo por las fuerzas militares y las falangistas (Hernández Burgos, 2011). Los tradicionalistas o requetés, herederos de los carlistas, debido a una promesa realizada a la Virgen de los Dolores de fundar una cofradía dedicada a su culto tras la guerra si finalmente el bando sublevado la ganaba, acabarían fundándola y teniendo su sede en la iglesia de San Pedro y San Pablo de la capital, pasando a formar parte de las imágenes veneradas durante la Semana Santa granadina (López-Guadalupe y López-Guadalupe, 2002).

Los actos conmemorativos del 18 de julio en Granada.

Granada celebrará el tercer aniversario del Alzamiento con diversos actos conmemorativos. En la mañana del día 18 se celebrará un solemne Tedeum en acción de gracias por la liberación en los primeros momentos de la sublevación.

13. 30/05/1939, pág. 6 . 
Seguidamente, en el Paseo del Salón tendrá lugar un gran acto de homenaje a las fuerzas liberadoras de Granada. Formarán representaciones de todos los cuerpos y la Falange leerá su mensaje de gratitud. Terminado el acto serán depositadas coronas en la Cruz de los Caídos. ${ }^{14}$

En las zonas rurales también se celebraría ampliamente la festividad del 18 de julio, mostrando así el compromiso de las fuerzas vivas locales (militares, falangistas, civiles, eclesiásticas) con la causa que les había llevado a la victoria y a sus puestos de mando. La asistencia masiva de los vecinos era un hecho señalado en la prensa para mayor gloria del régimen y de los apoyos sociales con los que, al menos discursivamente, contaba. Cabe destacar cómo, especialmente en los pueblos, la nueva ritualidad vinculada al régimen se combinaría con la que era propia de los mismos, y especialmente del carácter festivo más popular como en el caso que señalamos, con carrera de cintas como ocurre con los festejos patronales en muchas localidades de la provincia y con la actuación de la banda de música local. Esta relación entre lo nacional, representado en la celebración de la jornada de la sublevación que había pasado a formar parte del discurso mitificado de la guerra y del imaginario colectivo del país (Box, 2004), y lo local, a través de estas formas populares de festejo, ayudaría a reforzar la conjunción entre la España rural, uno de los puntales narrativos del régimen (Entrena, 1998), y el nuevo gobierno y sus instituciones.

Cuevas del Campo. La festividad del 18 de julio.

El pasado martes se celebró en esta localidad, para conmemorar la iniciación del Glorioso Movimiento, una misa de campaña a la que asistieron las autoridades militares y civiles, fuerzas de la guarnición, milicias femeninas y masculinas de Falange Española Tradicionalista y de las JONS y el pueblo en masa. A continuación hubo un brillante desfile por las mencionadas fuerzas y se bendijeron solemnemente los locales de Auxilio Social y Falange. Se celebró una comida organizada por las autoridades civiles en honor del Ejército nacional a la que asistió una representación de las fuerzas aquí destacadas. Por la tarde corrida de cintas y otros festejos amenizados por la banda de música local. ${ }^{15}$

El culto a las advocaciones patronales, sobre todo las marianas, sería de gran importancia dado que al estar muy enraizadas en el fervor religioso popular podían ser vinculadas a la nueva espiritualidad nacionalcatólica a través de eucaristías y rituales festivos, como el caso de las romerías como la que antes mencionábamos. Algunas de estas devociones se extendían y extienden aún en la actualidad por amplios territorios, como es el caso de la Virgen de las

14. 15/07/1939, pág. 4 .

15. 22/07/1939, pág. 4.

Pasado y Memoria. Revista de Historia Contemporánea, 24, 2022, pp. 239-266 
Nieves, que ejerce desde el siglo XVIII una suerte de patronazgo sobre el macivo montañoso de Sierra Nevada y algunos de los pueblos situados en sus laderas (Titos, 2017). Las organizaciones ligadas al montañismo, que tendrían un auge tras la guerra, vinculándose en parte a las organizaciones de FET y de las JONS, le iban a rendir culto en acción de gracias por la victoria. Es el caso del Club Penibético, que en lo alto de la sierra celebraría una misa dedicada a la memoria de los caídos en dicha zona que se dedicaban al alpinismo, una forma de deporte que ya a principios de siglo iría adquiriendo importancia.

En honor de la Virgen de las Nieves se celebró el domingo una Misa en Sierra Nevada.

La organizó el Club Penibético que reanudó así sus actividades. [...] la misa, celebrada frente a los albergues Universitario y de Obras Públicas -que saben de relatos montañeros y de gestas de guerra- tenía un doble significado, al ser ofrecida como homenaje a la Virgen de las Nieves, Patrona de nuestras montañas, y a los Caídos del Grupo Alpino, que supieron verter con heroismo, en la callada blancura del paisaje, todo el ardido torrente de su sangre moza. Las voces que invocaban sus nombres resonaron reciamente por aquellas montañas. Ellos legaron a las sierras nuevas leyendas y han dejado flotando entre las peñas, junto a la caricia tenue de las nubes, unas estrofas de romance rimadas a golpe de heroismo. ${ }^{16}$

Este culto mariano debido a las organizaciones falangistas juveniles se iba a unir a las prácticas rituales propias del falangismo y de la victoria, en una combinación de elementos fascistizados y católicos, como en el caso de la visita a la basílica de la Virgen de las Angustias y a la cruz de los caídos de la capital llevada a cabo por los flechas que habían participado en los campamentos de la Alfaguara y de La Herradura y que visitaban la ciudad como colofón a su estancia en los mismos. De esta forma, junto a las prácticas rituales religiosas, como los cantos en acción de gracias y las eucaristías, que tendrían lugar en el espacio sagrado de la basílica, se ponían en práctica los rituales y la estética falangista, que tendrían lugar en un espacio de nueva sacralización como las cruces de los caídos, donde se combinaban el elemento religioso de la cruz y el nacionalsindicalista del yugo y las flechas, así como los himnos. El culto a las imágenes patronales, como la Virgen de las Angustias en este caso, patrona de la capital granadina y con una gran devoción en la provincia, representaría uno de los elementos fundamentales en la imbricación entre la ritualidad del régimen y la propia de la sociedad local en cuestión, resultando una ocasión propicia para la conmemoración de la victoria y el culto a los que habían caído por la misma. Esta relación entre régimen y religiosidad local, ritualidad y culto

16. 08/08/1939, pág. 4. 
a los caídos, provoca también una relación entre el nacionalcatolicismo y los elementos falangistas, que aunque en ocasiones chocaban en cuanto a intereses particulares o determinados aspectos doctrinales, como hemos señalado, en estos momentos podían ir de la mano para celebrar el final del conflicto y la consolidación del nuevo Estado.

Ayer regresaron los flechas de los campamentos. Visitaron el templo de Nuestra Patrona y la Cruz de los Caídos.

A las seis y media de la tarde de ayer regresaron los flechas y cadetes de nuestra Organización Juvenil que durante 25 días han permanecido en los campamentos juveniles de la Alfaguara y la Herradura. En el Humilladero fueron recibidos los expedicionarios por el delegado provincial de la O. J. camarada Cobos y el asesor de Milicias, camarada León. Seguidamente los flechas y cadetes se dirigieron a la Basílica de Nuestra Señora de las Angustias, donde cantaron una Salve en acción de gracias. Acto seguido desfilaron en correcta formación a la Cruz de los Caídos. En ella el camarada Cobos leyó la Oración a José Antonio, cantándose por último el «Cara al Sol». ${ }^{17}$

Dado que durante la etapa republicana los símbolos religiosos habían sido suprimidos de los espacios administrativos y educativos, como las escuelas, una vez finalizada la guerra en todo el territorio nacional estos símbolos, especialmente el crucifijo, serían repuestos con un amplio despliegue de celebraciones y una ritualidad donde de nuevo los elementos religiosos y falangistas se combinaban (Callahan, 1987; Del Arco, 2018). La educación, al suponer uno de los principales puntos de apoyo del régimen para administrar su doctrina y su moral a la población desde la infancia, y a pesar de la depuración que había sufrido la institución, podía resarcirse de su pasado rindiendo el debido culto a la victoria a través de las prácticas religiosas y de las ceremonias patrióticas. La prensa falangista alcanza, en ocasiones como el fragmento que mostramos a continuación, un elevado nivel en el tono propagandístico de la narración del acto, pretendiendo evocar al lector lo excelso, desde su punto de vista, de dichos eventos religiosos mezclados con elementos falangistas, aún en localidades lejanas de la provincia y tomadas al final de la guerra:

Albuñol. Reposición del crucifijo en las Escuelas Nacionales.

En el día de la Fiesta de la Raza y con espléndida concurrencia se ha verificado la solemne bendición y reposición de la sagrada imagen de Cristo Crucificado en las Escuelas Nacionales de esta localidad. A las ocho y media de la mañana partieron de todas las Escuelas los niños en ordenadas filas llevando a su cabeza la gloriosa enseña bicolor y los crucifijos, escoltados por una escuadra de flechas y por la banda de cornetas y tambores de la O. J. entonando vibrantes canciones patrióticas y religiosas. A las nueve de la mañana y con asistencia

17. 22/08/1939, pág. 2. 
de gran número de fieles dio comienzo la Santa Misa. En la presidencia, todas las autoridades civiles y militares. Banderas y Crucifijos en alto. Momentos sublimes de emoción, mil angelicales voces infantiles se alzaron emocionadas entonando cantos piadosos y alusivos a la fiesta que se celebra. ${ }^{18}$

La ritualidad del nuevo régimen tenía como ya hemos señalado uno de sus principales puntos de fuerza en el culto a la memoria de los caídos. Su sacrificio en el campo de batalla y en la retaguardia, defendiendo la causa de la sublevación en territorio contrario, era concebido como el mayor honor que se podía alcanzar y se entendía que a quienes se iban a encargar de guiar y forjar el nuevo Estado les correspondía no olvidar su esfuerzo y venerar su contribución a la victoria, que se estaba festejando. Así, por decreto de la jefatura encargada de la propaganda (lo cual da idea del carácter propagandístico y aleccionador de la decisión) se habría de erigir en cada localidad su correspondiente cruz de los caídos, con los nombres de los de la misma esculpidos y situadas en espacios lo suficientemente significativos como para albergar los actos rituales que se iban a organizar en su recuerdo. En la prensa aparecería el decreto por lo que los municipios quedaban enterados de la orden. La ritualidad estaba conformada por diversos momentos que solían estar bien estructurados para seguir un orden, con la colocación de coronas de flores al pie de la cruz, a modo de ofrenda, la lectura de la lista de los caídos locales, terminándose con oraciones y con los himnos correspondientes.

El 29 de Octubre se eregirá la Cruz de los Caídos en los pueblos donde aún no existe. En todos los pueblos se depositarán coronas al pie de la Cruz que recuerda a nuestros muertos.

Por la Jefatura de Propaganda se ha dado la siguiente orden:

«El día 29 de octubre lo celebrarán nuestros pueblos con emoción y fervor religioso. En honor de nuestros muertos, donde no estuviese levantada la Cruz de los Caídos, se alzará solemnemente este día. En los pueblos donde exista se renovará la corona de flores. Todo, con arreglo al siguiente ritual:

Asistirán al acto todos los falangistas de la localidad, los niños de las Organizaciones Juveniles y los de las Escuelas Nacionales, presididos por las Autoridades y Jerarquías de la Falange. Las muchachas de la Falange Femenina portarán una corona de flores que será depositada, como ofrenda emocionada, al pie de la Cruz. A continuación el Delegado de Propaganda leerá la lista de los Caídos de la localidad en defensa de la Causa Nacional. Seguidamente dará lectura a la Oración de los Caídos, de Rafael Sánchez Mazas. Y por último se rezará un responso por el eterno descanso de nuestros héroes y mártires. Las bandas de música, en los lugares donde haya, interpretarán, sólo al final, los himnos del Movimiento y el Nacional. ${ }^{19}$

18. 15/10/1939, pág. 6 .

19. $25 / 10 / 1939$, pág. 6 . 
Las diversas manifestaciones rituales, como hemos comprobado a través de la prensa falangista de la época, estaban dirigidas a la mayor gloria y ensalzamiento de la victoria lograda en el campo de batalla, teniendo como telón de fondo la ritualidad característica de las celebraciones cristianas que suponían una forma de respaldo a los festejos de 1939 y los años que lo seguirían. El franquismo aunaba, así, la estética ritual de los regímenes del periodo de entreguerras con la de los ritos católicos, y hacía de las eucaristías, las procesiones y las fiestas populares una ocasión para, a través de los sermones y las oraciones dedicadas a los caídos, introducir nuevas formas de culto que se unirían a las anteriores.

El nacionalcatolicismo, como doctrina de carácter patriótico y religioso, que concebía el ser católico como sinónimo del ser español, y por lo tanto el ser leal al nuevo régimen como una forma de ser «buen católico» y «buen español», ya que éste habría salvaguardado los valores cristianos contra el ateísmo y la furia anticlerical e iconoclasta, sería uno de los principales puntales ideológicos del franquismo, llegando a partir de mediados de los años cuarenta a desplazar al predominio nacionalsindicalista, y marcaría la trayectoria del mismo especialmente durante las primeras décadas, hasta que surgieran voces críticas a partir del Concilio Vaticano II y la irrupción del denominado cristianismo de base, más proclive a identificarse con las clases populares.

La instrumentalización de las creencias y rituales festivos vinculados a la religiosidad popular en casos como el andaluz, y en el caso que hemos tratado el de la provincia de Granada, es una muestra de la búsqueda de apoyos sociales por parte de las fuerzas vivas, tanto civiles como eclesiásticas, del régimen o ligadas al mismo, y que permitiría que su mensaje calara con más intensidad entre amplios sectores sociales. A pesar de esto, no siempre los propósitos nacionalcatólicos de inspiración institucional serían plenamente aceptados en su integridad por la sociedad y surgirían roces en la relación entre dicha doctrina y los rituales de la religiosidad popular como es el caso de las procesiones de imágenes, que serían vistas con recelo por algunos sectores eclesiásticos como una muestra de falta de interés por el dogma en contraste con el culto a imágenes, mucho más querido por el conjunto de la población (Rina, 2015, 2020b).

\section{Conclusiones}

En el marco de las investigaciones sobre la posguerra, que han ido incrementándose en las últimas décadas, uno de los aspectos que están comenzando a llamar la atención de los investigadores e investigadoras es la relación entre el régimen y diversos aspectos socioculturales, como es el caso de la religión y los rituales festivos, que serían instrumentalizados por el mismo en su afán de 
buscar apoyos sociales y relacionar la victoria y la doctrina oficial con el credo y las formas de festejo ya existentes en la sociedad española de la época, para afianzar a los acólitos a su causa y ganarse otros nuevos a través de la imbricación de nacionalismo y catolicismo. El nacionalcatolicismo, con tintes militares y falangistas adquiridos durante la guerra, de los que se iría desprendiendo con el paso del tiempo, iba a constituir el vehículo de unión de la fe y el patriotismo, como los valores que conformaban la base de la ideología del nuevo Estado surgido a partir de la sublevación del 18 de julio de 1936, que el 1 de abril de 1939 quedaba asentado en todo el territorio español. El apoyo de una gran parte de la institución eclesiástica a la sublevación, sobradamente mostrado desde el inicio del conflicto mediante la noción de la guerra como una cruzada, se mostraba también mediante la nueva cultura de la victoria surgida a partir del final del conflicto, en la que se mezclaban elementos religiosos, militares, tradicionalistas y falangistas. Esta cultura tomaba prácticas socioculturales previas y las resignificaba, mientras que al mismo tiempo creaba otras nuevas.

El ámbito de las creencias religiosas y los rituales vinculados a las mismas, tales como procesiones, romerías y fiestas patronales serviría para mostrar la devoción de cada localidad a la par que el agradecimiento de la misma por la victoria y el apoyo de la población hacia las fuerzas vivas, es decir las élites municipales, que a nivel local representaban al régimen. La religiosidad popular como manifestación más clara de devoción compartida por amplios sectores de la población se iba a ligar al nacionalcatolicismo y a las formas de ritualidad propias del nuevo Estado, a través de los desfiles militares y falangistas, el culto a los caídos durante la guerra y las misas y romerías en acción de gracias por la protección divina y la victoria. Dichas formas de ritualidad serían mostradas en la prensa del momento como un elemento propagandístico a favor de la sintonía entre clero, sociedad y autoridades y organizaciones del régimen.

Los espacios dedicados a la celebración de rituales conmemorativos y religiosos iban también a ampliarse. Así, además de los tradicionales, como los templos (iglesias, basílicas, catedrales), los diversos monumentos dedicados a la memoria de los caídos, tanto José Antonio Primo de Rivera como los de cada localidad, constituían lugares donde la colectividad recordaba a sus mártires por la causa de los sublevados y donde podía desplegarse la ritualidad de los brazos en alto, los himnos y los vítores, junto con la estética de las camisas azules y las banderas. Las cruces se erigían para engalanarse con yugos y flechas, símbolo de la unión entre la nación, el partido único y el credo oficial, en una simbiosis que configuraba la nueva forma de españolidad que se procuraba que fuera aceptada. 
La relación entre rituales religiosos y rituales militarizados y fascistizados no siempre sería aceptada de buena gana por algunos miembros del alto clero, que consideraban que dichos elementos externos a la propia religión eran incompatibles con el trasfondo de la misma, llegando a criticar tanto los brazos en alto saludando a las imágenes religiosas, práctica bastante extendida durante los primeros años de posguerra, como los excesos que achacaban al culto a las imágenes. La existencia de fricciones en este aspecto entre las autoridades civiles y eclesiásticas, sin embargo, y a pesar de su relevancia en algunos casos, no sería obstáculo para que el nacionalismo propugnado por el régimen se pudiera seguir vinculando durante las décadas siguientes al catolicismo como religión del Estado. La prensa, como la falangista en el caso que hemos tratado, no haría especial mención a las posibles disensiones internas sino que trataría de mostrar una imagen de unidad al finalizar la guerra, poniéndose al servicio propagandístico del régimen y combinando el mensaje de inspiración nacionalsindicalista con el del nacionalcatolicismo.

\section{Bibliografía}

ÁLVAREZ JUNCO, José (2017). Dioses útiles. Naciones y nacionalismos. Barcelona: Galaxia Gutenberg, S.L.

BARRIOS ROZÚA, Juan Manuel (1995). Conflictividad social y destrucción de bienes religiosos en la ciudad de Granada durante la Segunda República. Revista del Centro de Estudios Históricos de Granada y su Reino, 9, 185-223.

BARRIOS ROZÚA, Juan Manuel (2008). Las destrucciones iconoclastas durante la Guerra Civil y su papel en la propaganda franquista. Investigaciones históricas. Época moderna y contemporánea, 28, 185-200.

BOTTI, Alfonso (1992). Cielo y dinero. El Nacionalcatolicismo en España, 18811975. Madrid: Alianza Editorial.

BOX VARELA, Zira (2004). Secularizando el Apocalipsis. Manufactura mítica y discurso nacional franquista: la narración de la victoria. Historia y Política, 12, 133-160.

CALLAHAN, William (1987). The Evangelization of Franco's «New Spain». Church History, 56, 491-503. https://doi.org/10.2307/3166430

CALLAHAN, William (2007). La Iglesia católica en España (1875-2002). Barcelona: Editorial Crítica.

CASTRO, Luis (2020). "Yo daré las consignas». La prensa y la propaganda en el primer franquismo. Madrid: Marcial Pons.

COBO ROMERO, Francisco (2015). La construcción simbólica del franquismo. Mitos, ritos y discursos para la legitimación del Nuevo Estado. En Antonio BARRAGÁN MORIANA (coord.). La articulación del franquismo en Andalucía (19-58). Sevilla: Centro de Estudios Andaluces. 
DEL ARCO BLANCO, Miguel Ángel (2018). Before the Altar of the Fatherland: Catholicism, the Politics of Modernization, and Nationalization during the Spanish Civil War. European History Quarterly, 48 (2), 232-255. https://doi. org/10.1177/0265691418760169

DELGADO IDARRETA, J. M. (2004). Prensa y propaganda bajo el franquismo. En Nathalie LUDEC; Françoise DEBOSQUET (coords.). Centros y periferias. Prensa, impresos y territorios en el mundo hispánico contemporáneo: homenaje a Jacqueline Covo-Maurice (219-231). Burdeos: Université Michel de MontaigneBordeaux 3.

DELGADO RUIZ, Manuel (1992). La ira sagrada. Anticlericalismo, iconoclastia y antirritualismo en la España contemporánea. Barcelona: Humanidades.

DI FEBO, Giuliana (2002). Ritos de guerra y de victoria en la España franquista. Madrid: Desclée.

ENTRENA DURÁN, Francisco (1998). Cambios en la construcción social de lo rural. De la autarquía a la globalización. Madrid: Editorial Tecnos, S.A.

HERNÁNDEZ BURGOS, Claudio (2011). Granada azul. La construcción de la «Cultura de la Victoria» en el primer franquismo. Granada: Comares.

HERNÀNDEZ I MARTÍ, Gil-Manuel (2002). La festa reinventada. Calendari, política i ideologia en la València franquista. Valencia: Universitat de València.

LÓPEZ-GUADALUPE, Miguel Luis; LÓPEZ-GUADALUPE, Juan Jesús (2002). Historia viva de la Semana Santa de Granada. Arte y devoción. Granada: Universidad de Granada.

MANCHA CASTRO, José Carlos (2018). La Semana Santa y la recatolización de Huelva. Un acercamiento a la construcción simbólica del franquismo de posguerra. Pasado y Memoria. Revista de Historia Contemporánea, 17, 413-452. https://doi.org/10.14198/PASADO2018.17.15

MASSA, Paola (1998). Antropología y patrimonio cultural. Un estudio sobre los monumentos a los caídos. Alteridades, 8 (16), 85-94.

MOLINERO RUIZ, Carme (2005). La captación de las masas. Política social y propaganda en el régimen franquista. Madrid: Cátedra.

MONTERO GARCÍA, Feliciano (2003). La historia de la Iglesia y del catolicismo español en el siglo XX. Apunte historiográfico. Ayer, 51, 265-282.

MORENO SECO, Mónica (2001). El conflicte inexistent. Església i Falange a Alacant, 1939-1945. Plecs d'història local, 95, 1492-1493.

MORENO SECO, Mónica (2002). Creencias religiosas y política en la dictadura franquista. Pasado y Memoria. Revista de Historia Contemporánea, 1, 111-130. https://doi.org/10.14198/PASADO2002.1.05

ORTIZ GARCÍA, Carmen (1997). Folklore y franquismo. En Rafael HUERTAS y Carmen ORTIZ (eds.). Ciencia y fascismo (161-180). Aranjuez: Ediciones Doce Calles. 
QUIROGA FERNÁNDEZ DE SOTO, Alejandro (2007). Los orígenes del nacionalcatolicismo. José Pemartín y la Dictadura de Primo de Rivera. Granada: Comares.

RICHARDS, Michael (2010). Presentando armas al Santísimo Sacramento: Guerra Civil y Semana Santa en la ciudad de Málaga, 1936-1939. En Chris EALHAM; Michael RICHARDS (eds.). España fragmentada. Historia cultural y Guerra Civil española (253-286). Granada: Comares.

RINA SIMÓN, César (2015). La construcción de los imaginarios franquistas y la religiosidad «popular», 1931-1945. Pasado y Memoria. Revista de Historia Contemporánea, 14, 179-196. https://doi.org/10.14198/PASADO2015.14.07

RINA SIMÓN, César (2015). Los imaginarios franquistas y la religiosidad popular (1936-1949). Badajoz: Diputación de Badajoz.

RINA SIMÓN, César (2017). Fascismo, nacionalcatolicismo y religiosidad popular. Combates por la significación de la dictadura (1936-1940). Historia y Política, 37, 241-266. https://doi.org/10.18042/hp.37.09

RINA SIMÓN, César (2020a). Imaginar Iberia. Tiempo, espacio y nación en el siglo XIX en España y Portugal. Granada: Comares.

RINA SIMÓN, César (2020b). El mito de la tierra de María Santísima. Religiosidad popular, espectáculo e identidad. Sevilla: Centro de Estudios Andaluces.

RODRÍGUEZ BECERRA, Salvador (2000). Religión y Fiesta. Antropología de las creencias y rituales en Andalucía. Sevilla: Signatura Demos.

RODRÍGUEZ LÓPEZ, Sofía (2010). La Sección Femenina, la imagen del poder y el discurso de la diferencia. Feminismo/s, 16, 233-257. https://doi.org/10.14198/ fem.2010.16.11

ROMÁN RUIZ, Gloria (2020). Franquismo de carne y hueso. Entre el consentimiento y las resistencias cotidianas (1939-1975). Valencia: Universitat de València.

TITOS MARTÍNEZ, Manuel (2017). Las cuatro ermitas de Sierra Nevada. Granada: Editorial Atrio.

VINCENT, Mary (2017). La Semana Santa en el nacionalcatolicismo: espacio urbano, arte e historia. El caso de Valladolid (1939-1949). Historia y Política, 38, 91-127. https://doi.org/10.18042/hp.38.04

ZALBIDEA BENGOA, Begoña (2005). Prensa de Bilbao durante el franquismo. Bidebarrieta. Revista de humanidades y ciencias sociales de Bilbao, 16, 287-305. 